\title{
CHAPADAS: RELICT OF MID-CRETÁCEOUS INTERIOR SEAS IN BRAZIL (1)
}

\section{MITSURU ARAI}

\begin{abstract}
In the mid-Cretáceous, particularly during Albian-Turonian time, the greatest eustatic sea level rise in Phanerozoic history triggered a global transgressive event. This resulted in sedimentary filling of then-existing intracontinental depressions. Following the Highstand Phase, the non-subsiding areas ceased receiving sediment and underwent erosion at their margins. In Brazil, these areas were subsequently uplifted, mainly in post-Neogene time, to constitute plateau-like geomorphologic units termed chapadas (e.g., Apodi, Araripe, Parecis, and Urucuia).

The relationship between the mid-Cretáceous marine transgression and the origin of chapadas has been pointed out in our previous works. Chapadas have tabular geometry, and their lithostratigraphic units are horizontal and have notable lateral continuity. Marine fossils of some strata of the chapada units reinforce this model. The only chapada that does not have marine paleontologic evidence is Parecis. However, this may simply reflect inadequate knowledge. Paleontological and paleocurrent data available point to interconnection among the chapada-bearing basins and, moreover, their connection to the Pacific and Central and South Atlantic oceans.

Keywords: Chapada, Brazil, South Atlantic, mid-Cretáceous
\end{abstract}

INTRODUCTION Extensive plateau-like geomorphologic units, known as chapadas, occur in several regions of Brazil. Their origin has not been well understood; some authors (e.g., Ab'Sáber 1969) suggest they are products of pediplanation. Recent data (e.g., Arai et al. 1998, Aral 1999) relate the origin of chapadas to the mid-Cretáceous marine transgression.

The global marine transgression of the mid-Cretáceous - virtually unparalleled in the Earth's Phanerozoic history - elevated sea level to about $300 \mathrm{~m}$ above the present datum (Vail et al. 1977) and left its signature in several parts of the world. However, in Brazil there remains a considerable reluctance to accept the existence of midCretáceous interior seas. Thus, most paleogeographic reconstructions of the Brazilian Cretáceous do not show any significant marine flooding of inland areas. At its maximum, the marine invasion probably produced a system of seaways extending across South America and connecting the Pacific Ocean with the North and South Atlantic oceans.

This paper aims to demonstrate that, during mid-Cretáceous (Aptian through Cenomanian) time, an interior sea developed over the area of present-day Brazil, and that chapadas represent relics of that paleo-sea.

HISTORICAL SYNOPSIS Although the idea of Brazilian interior sea may seem audacious, even incongruous, it is not entirely new. Termier and Termier (1952, p. 326-327, carte XXVIII) presented a Late Cretáceous paleogeographic map, wherein seas designated "mers mal connues" (poorly known seas) were identified over areas corresponding to the Parnaíba, São Francisco, and Parecis basins.

Subsequently, Stokes (1965, p. 260, fig. 12.10a) depicted an extensive belt of Cretáceous marine sedimentation encompassing several Brazilian basins; viz., São Francisco, Parana (northern part thereof), Parecis, Acre, and interior basins of northeast Brazil (Araripe, Sousa, Iguatu, etc). He suggested the connection of these basins with coeval, predominantly marine basins of Peru and Colombia.

These publications can be regarded as having pioneered the hypothesis advanced herein. However, they provided no concrete data in support to their interpretations.

Unequivocal evidence of the mid-Cretáceous presence of interior sea in Brazil is traditionally cited from the area embracing the Parnaíba and Araripe basins of northeast Brazil (Beurlen 1971, Braun 1966, Arai et al. 1994). Some authors also propose that these basins were connected to the Sergipe/Alagoas Basin (Silva-Santos 1991) or to the Potiguar Basin (Lima 1978, Viana 1998).

Kattah (1991) suggests more extensive development of Cretáceous interior sea. Based on the occurrence of radiolarians in the Sanfranciscan Basin, this author advocates interconnection, during Aptian time, of the Sanfranciscan, Parnaíba, Araripe, and Potiguar basins.

EVIDENCE The presence of mid-Cretáceous interior sea in Brazil can be advocated on the grounds of geomorphological, stratigraphic, sedimentological, paleontological, and geochemical information.

Geomorphological evidence The concept that chapadas are the most conspicuous remnants of the mid-Cretáceous marine transgression is proposed by Arai et al. (1998), based on their tabular geometry, horizontality, and lateral extent. According to IBGE (1993), Brazil has four Cretáceous geomorphological units that constitute true chapadas: viz., Araripe, Meio-Norte, Sanfranciscan, and Parecis. The chapada of Araripe is the topographic expression of the Araripe Group, which comprises the Rio da Batateira, Santana, Arajara, and Exu formations. The Areado, Codó, and Itapecuru formations (and their correlatives) constitute the chapadas of Meio-Norte. The Chapada of São Francisco is made up of the Areado, Urucuia, and Mata da Corda formations.

The summits of the chapadas are constituted by primitive surfaces (sensu Fortes 1992) and represent neither erosion surfaces (pediplains) nor exhumed surfaces. They result from abrupt interruptions in deposition.

Stratigraphic evidence In several Brazilian basins, midCretáceous sequences are characterized by very extensive, laterally continuous units: e.g., Jaquirana Group in the Acre Basin; Alter do Chão Formation (lower part), Amazonas Basin; Grajau/Codó/ Itapecuru system, Parnaíba Basin; Alagamar/Agu/Jandaira system, Potiguar Basin; Araripe Group, Araripe Basin; Areado/Urucuia/Mata da Corda system, Sanfranciscan Basin; and Parecis Formation, Parecis Basin. These units are coeval and were deposited during the Highstand Eustasy, and originally extended well beyond the limits of the basins in which they now occur. The sandy units capping and preserving most chapadas are considered to be fluvial; these originated by normal regression (progradation occurred under high standing sea level) which culminated in the infilling of the basins.

Isolated occurrences of strata correlative with those of the chapadas occur as small remnants on crystalline basement terranes. One of the more recently reported occurrences of such vestiges, correlated with the Abaete Formation (=Abaete Member of Areado Formation) of the Sanfranciscan Basin, occurs in the vicinity of Brasflia-DF (Campos et al. 1999).

Sedimentological evidence Fades typical of fluvial systems are conspicuous within the chapada strata, but recent studies reveal features of transitional and marine environments in some of the cited above units (e.g., Souto et al. 1990, Anaisse Jr. et al. 1999, Dias-Lima and Rossetti 1999). In the Sanfranciscan Basin, Barcelos and Suguio (1981) documented sedimentological characteristics consonant with shallow marine deposition in some samples of the Areado and Urucuia formations. Castro (1996), who reported sedimentary structures suggestive of a transgressive, marginal-marine setting associated with cherty strata reaffirms the marine nature of the Areado Formation. Primary structures in the regressive caprock units of the Araripe (Exu Formation) and Sanfranciscan (Urucuia Formation) Basins indicate that paleocurrents flowed respectively to the west (Assine 1997) and southwest (Campos and Dardenne 1997), implying in the existence of a westerly major marine depositional basin in mid-Cretáceous.

Paleontological evidence Mid-Cretáceous marine fossils occur in several Albian-Aptian formations of interior Brazil. The following inventory is based on records by Lima (1979a,b; 1982), except where specifically credited to other authors.

AREADO FORMATION: fishes, dinoflagellates (Arai, apud Kattah 1991), radiolarians (Kattah 1991, Kattah and Koutsoukos 1992, Pessagno and Dias-Brito 1996, Dias-Brito et al. 1999), and 
foraminifers (Dias-Brito et al 1999).

CODO FORMATION: fishes, mollusks, dinoflagellates (Arai, apud Paz and Rossetti 1999; Antonioli et al. 1999), and foraminifers.

SANTANA FORMATION: fishes, mollusks, dinoflagellates, foraminifers (Arai and Coimbra 1990), echinoids, and turtles.

The marine fossils occur in transgressive units that characterize the basal portions of the cited above formations. Lithology becomes progressively more sandy upward, concomitant with increasing fluvial influence, thereby diminishing the likelihood of recovering body fossils. However, trace fossils can be found in the regressive deposits. For example, the Arajara Formation (="Exu inferior", Araripe Basin) contains Diplocraterion (unpublished data), Skolithos, and Taenidium. Besides two later genera, Fernandes et al. (1998) report other indeterminate trace fossils. This formation has several intervals rich in trace fossils, suggesting deposition under neritic conditions.

Geochemical evidence The most convincing geochemical data are of gypsite/anhydrite beds of the Codó Formation. According to Rodrigues (1995), these present ${ }^{87} \mathrm{Sr} /{ }^{86} \mathrm{Sr}$ isotopic ratios between 0.708000 and 0.708800 , compatible with a marine origin. The shales just below the gypsite/anhydrite represent the maximum flooding surface of the Codó Formation, whose biomarkers are marine (e.g., dinosterane e $\mathrm{C}_{30}$ sterane). The same biomarkers were found in the transgressive tract of the Alagamar Formation (Potiguar Basin), represented by the Ponta do Tubarão beds and by the basal unit of the Galhinhos Shale(Vasconcelos 1995).

DISCUSSION AND CONCLUSION Besides the eustatic rise of the sea level, the geodynamic situation immediately prior to the BrazilAfrica separation - involving depression of the continental crust under an extensional tectonic regime - would probably, in itself, have promoted invasion by an extensive interior sea during the latest Early Cretáceous (Aptian)

The subsequent eustatic sea level drop had extensive erosional consequences. The initial major decline occurred at the end of Albian, producing the worldwide sequence boundary that is evident at the upper Albian-lower Cenomanian transition (Pereira 1996). This event resulted in a rapid influx of coarse clastic sediments into basins of the continental margin, and, thereby, the formation of important turbiditic petroleum reservoirs (e.g., Namorado Sandstone of the Campos Basin).

As shown by figure 1, there is a relationship between the areas of chapadas and the Mesoproterozoic Domain. Further investigation of this relationship, added to study of the origin of Brazilian kimberlites (which seem to occur in areas adjacent to chapadas), could well improve the understanding of the influence of the crystalline basement on subsidence and uplift of the cratonic area. This would, moreover, improve the knowledge of the original geographic extent of the nowdenuded sedimentary cover.

Among the basin relics represented by the chapadas, only the Parecis Basin does not, as yet, provide any concrete evidence of association with the mid-Cretáceous interior sea. Its inclusion in that paleogeographic scenario is currently based exclusively on geomorphological and stratigraphic characteristics. However, the lack

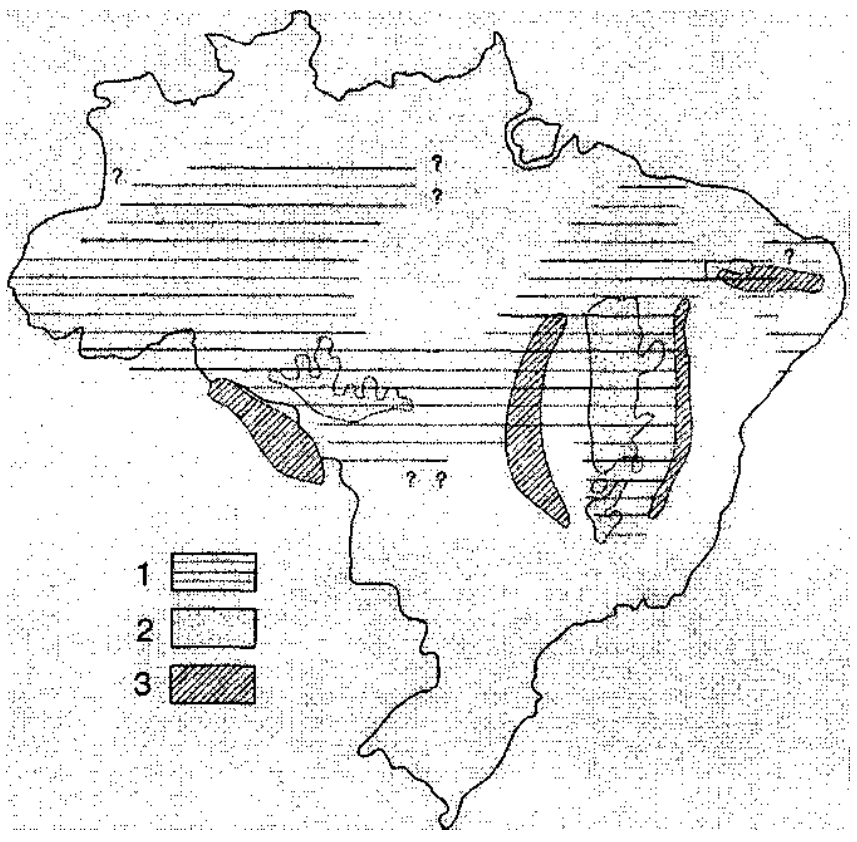

Figure I - Possible extent of mid-Cretáceous interior sea in Brazil and its relationship with occurrences of present-day chapadas and the Mesoproterozoic Domain (the latter after Brito Neves et al. 1996). Legend: 1. Mid-Cretáceous interior seas, 2. Cretáceous chapadas, 3. Mesoproterozoic domain.

of evidence may simply reflect insufficient knowledge of the Parecis Basin. Siliceous concretions are reportedly common in sandstones of the Parecis Formation (Oliveira 1915, p. 33, apud Santos and Loguercio 1984, p. 122). It is possible that these are actually chert bodies containing radiolarians similar to those known from the Sanfranciscan Basin.

Acknowledgements The author is especially grateful to the following colleagues (cited in alphabetical order): Benjamim Bley de Brito-Neves, Carlos Emanoel de Souza Cruz, Cecflia C. Lana, Claudio Coelho de Lima, Francisco Fontes Lima Neto, Jarbas Vicente P. Guzzo, José Henrique G. de Melo, Leonardo Borghi de Almeida, Luciano Seixas Chagas, Maicio José Pereira, Noevaldo A. Teixeira, Rodi Avila Medeiros (deceased), Peter Szatmari, and Seirin Shimabukuro. The author also thanks Professor Geoffrey Playford (The University of Queensland, Brisbane, Australia) for reviewing the manuscript and suggesting amendments, PETROBRAS - Petróleo Brasileiro S.A permit the publication of this paper, and to two anonimous reviewers of $\mathrm{RBG}$ for their suggestions.

\section{References}

Ab'Saber A.N. 1969. Participação das superfícies aplainadas nas paisagens do Nordeste Brasileiro. Geomorfologia 19:1-38.

Anaisse Jr. J., Truckenbrodt W., Rossetti D.F., Góes A.M. 1999. Estruturas geradas por ondas e maré nos depósitos Itapecuru (Älbiano superior - Cenomaniano), região de Açailândia/MA, Bacia do Grajaú. In: Simpósio sobre o Cretáceo do Brasil, 5, Serra Negra 1999. Boletim...Rio Claro, UNESP, p.367-373.

Antonioli L, Thiago L.K., Rodrigues M.A.C., Dino R. 1999. Análise palinoestratigáfica de sedimentos aptianos da Bacia do Parnaíba, aflorantes na regiâo de Codó, MA. In: Congresso Brasileiro de Paleontologia, 16, Crato 1999. Boletim de Resumos...Crato, SBP,p.18-19.

Arai M. 1999. A transgressão marinha mesocretácea: sua implicação no paradigma da reconstituicão paleogeografica do Cretáceo no Brasil. In: Simpósio sobre o Cretáceo do Brasil, 5, Serra Negra 1999. Boletim...Rio Claro, UNESP, p.577-582.

Arai M. and Coimbra J.C. 1990. Analise paleoecológica do registro das primeiras ingressões marinhas na Formação Santana (Cretáceo Inferior da Chapada do Araripe). In: I marinhás na Formação Santana (Cretáceo Inferior da Chapada do Araripe). In: I Simposio sobre a Bac

Arai M., Lana C.C., Pedrão E. 1994. Ecozona Subtilisphaera spp.: Registro eocretáceo de um importante episódio ecológico do Oceano Atlântico primitivo. Acta Geologica Leopoldensia, v. XVII, N 39/2: 521-538.

Arai M., Pereira M. J., Shimabukuro S. 1998. Origem dos chapadôes brasileiros: uma analise à luz da estratigrafia de sequências. In: Congresso Brasileiro de Geologia, 40, Belo Horizonte, Anais..., p. 86.
Assine M.L. 1997. Paleocorrentes e paleogeografia na bacia do Araripe, Nordeste do Brasil. Revista Brasileira de Geociências, 24:223-232. (December 1994 issue delivered in 1997)

Barcelos J.H. and Suguio K. 1981. Estudos sedimento!6gicos da Formação Areado, Cretáceo da Bacia Sanfranciscana. Revista Brasileira de Geociências, 11:247-256.

Beurlen K. 1971. As condições ecológicas e faciológicas da Formacão Santana na Chapada do Araripe (Nordeste do Brasil). Anais Academia Bras. Ciencias, 43(Suplemento):411-415.

Braun O.P.G. 1966. Estratigrafia dos sedimentos da parte interior da Região Nordeste do Brasil (Bacias de Tucano-Jatobá, Mirandiba e Araripe). Rio de Janeiro, DNPM/ DGM, 81pp. (Boletim DNPM/DGM, 236)

Brito-Neves B.B., Winge M., Carneiro M.A. 1996. Orogêneses precedendo e tafrogeneses sucedendo Rodínia na América do Sul. Boletim IG-USP, Ser. dent., 27:1-40.

Campos J.E.G. and Dardenne M.A. 1997. Estratigrafia e sedimentação da Bacia Sanfranciscana: uma revisão. Revista Brasileira de Geociências, 27:269-282.

Campos J.E.G., Freitas-Silva F.H., Dardenne M.A. 1999. Ocorrencia de conglomerados da Formação Abaeté Cretáceo Inferior da Bacia Sanfranciscana, na Região do Distrito Federal. In: Simpósio sobre o Cretáceo do Brasil, 5, Serra Negra 1999. Boletim...Rio Claro, UNESP, p.339-343.

Castro J.C. 1996.0 Cretáceo da porção sul da Bacia Sanfranciscana: uma breve revisão. In Simpósio sobre o Cretáceo do Brasil, 4, Rio Claro 1996. Boletim...Rio Claro, UNESP, p.209-211. 
Dias-Brito D., Pessagno E.A. Jr, Castro J.C. 1999. Novas considerações cronoestratigráficas sobre o silexito a radiolários do sul da Bacia Sanfranciscana, Brasil, e a ocorrência de foraminíferos planctônicos nestes depósitos. In: Simpósio sobre o Cretáceo do Brasil, 5, Serra Negra 1999. Boletim...Rio Claro, UNESP, p.567-575.

Dias-Lima R. and Rossetti D.F. 1999. Análise faciológica e estratigráfica de depósitos do Cretáceo Superior, leste da Bacia do Grajaú, Maranhão. In: Simpósio sobre o

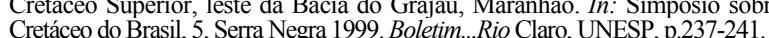

Fernandes A.C.S., Srivastava N.K., Reis R.P.B.P, Henriques M.H.P., Carvalho, I.S. 1998 A icnofauna de invertebrados da Formação Arajara (Bacia do Araripe, Cretáceo Inferior). In: Congresso Brasileiro de Geologia, 40, Belo Horizonte, Anais..., p. 443.

Fortes P.P. 1992. As superficies primitivas das chapadas da bacia do Parnaíba. In: Congresso Brasileiro de Geologia, 37, São Paulo, Boletim de Resumos Expandidos, v. 2 (Sessoes Tematicas), p. 270-271.

IBGE. 1993. Mapa de Unidade de Relevo do Brasil - escala 1:5.000.000. Rio de Janeiro, Fundação Institute Brasileiro de Geografia e Estatística ( $1^{\mathrm{a}}$ edição).

Kattah S.S. 1991. Analise faciologica e estratigrafica do Jurdssico Superior/ Cretáceo Inferior na porcao meridional da Bacia Sanfranciscana, oeste do estado de Minas Gerais. Ouro Preto. Universidade Federal de Ouro Preto. Departamento de Geologia. Dissertação de Mestrado, 227pp.

Kattah S.S. and Koutsoukos E.A.M. 1992. A ocorrência de radiolários em fácies sedimentares de origem marinha no Mesozóico da Bacia Sanfranciscana. Revista Escola de Minus, Ouro Preto, 45:214.

Lima M.R. 1978. Palinologia da Formação Santana (Cretáceo do Nordeste do Brasil). São Paulo, Universidade de São Paulo. Tese de Doutoramento, $335 \mathrm{pp}$

Lima M.R. 1979a. Paleontologia da Formação Santana (Cretáceo do Nordeste do Brasil): estágio atual de conhecimentos. Anais Academia Bras. Ciências, 51:546-556.

Lima M.R. 1979b. Palinologia dos calcários laminados da Formação Areado, Cretáceo de Minas Gerais. In: Simpósio Regional de Geologia, 2, Rio Claro 1979. Atas...Rio Claro, Sociedade Brasileira de Geologia. v. 1, p.203-216.

Lima M.R. 1982. Palinologia da Formação Codó na região de Codó, Maranhão. Boletim IGUSP, 13:116-128

Paz J.D.S. and Rossetti D.F. 1999. Análise faciológica da Formação Codó (Aptiano superior) na região de Codó (MA), leste da Bacia do Grajaú. In: Simpósio sobre o Cretáceo do Brasil, 5, Serra Negra 1999. Boletim...Rio Claro, UNESP, p.201-206.

Pereira M.J. 1996. O limite de sequência Neo-albiano/ Eocenomaniano na placa sul-americana e suas implicações geodinâmicas e paleogeográficas. In: Simpósio sobre o Cretáceo do Brasil, 4, Rio Claro 1996. Boletim...Rio Claro, UNESP, p.47-50.
Pessagno E.A. Jr and Dias-Brito D. 1996. O silexito a radiolários do sul da Bacia Sanfranciscana, Brasil: idade, origem e significado. In: Simpósio sobre o Cretáceo do Brasil, 4, Rio Claro 1996. Boletim...Rio Claro, UNESP, p.213-221

Rodrigues R. 1995. A Geoquímica Orgânica na Bacia do Parnaiba. Porto Alegre-RS. Tese de Doutorado. Universidade Federal do Rio Grande do Sul-UFRGS, $225 \mathrm{pp}$

Santos J.O.S. and Loguercio S.O.C. 1984. A parte meridional do Cráton Amazônico (Escudo Brasil-Central) e as bacias do Alto Tapajós e Parecis-Alto Xingu. In: Schobbenhaus G, Campos D.A., Derze G.R., Asmus H.E. (eds.) Geologia do Brasil - Texto explicativo do mapa geológico do Brasil e da área oceânica adjacente inchindo depósitos minerais Escala 1:2500000. Brasilia, Departamento Nacional de cluindo depósitos minerais, Esc

Silva-Santos R. 1991. Fosseis do Nordeste do Brasil: paleoictiofáunula da Chapada do Araripe. Rio de Janeiro, Universidade do Estado do Rio de Janeiro, Departamento de Biologia Animal e Vegetal, $64 \mathrm{pp}$.

Souto D.L.A.N., Preda W.N., Farias P.R.C. 1990. Sistemas deposicionais e geometria dos reservatorios da Formação Acu no Alto de Mossoró, Bacia Potiguar. In: Congresso Brasileiro de Geologia, 36, Natal, Anais..., v. 1, p.241-255.

Stokes W.L. 1965. An introduction to Historical Geology. Nova Delhi, Prentice-Hall of India Ltd., 502 pp.

Termier H. and Termier G. 1952. Histoire Geologique de la Biosphere. Paris, Masson and Cie, Editeurs, 721 pp., 35 maps.

Vail PR. Mitchum RM. Jr, Thompson S. III. 1977. Seismic Stratioraphy and Global Changes of Sea Level, Part 4: Global Cycles of Relative Changes of Sea Level. In: Payton C.E. (ed.) Seismic Stratigraphy - Applications to hydrocarbon exploration p 83-97 (AAPG Memoir, 26)

Vasconcelos E.P. 1995. O Evento CPT (Camadas Ponta do Tubarão), Aptiano da Bacia Potiguar. Porto Alegre-RS. Dissertação de Mestrado. Universidade Federal do Rio Grande do Sul-UFRGS, $198 \mathrm{pp}$.

Viana M.S.S. 1998. The Proto-Atlantic Albian way and its influence on the South AmericanAfrican life. Boletin de la Asociación Paleontologica del Golfo San Jorge, 2 (Edition Especial), Ano I: 32-34.(paper presented at 3rd Annual Conference of IGCP Project 381, Comodoro Rivadavia, Argentina, November 17-20,1998)

Contribution IGC-088

Received February 2,2000 Accepted for publication April 1,2000 